\title{
Dialogue Among Civilizations: Some Exemplary Voices
}

Fred Dallmayr

Palgrave, New York \& Basingstoke, 2002, xi $+282 \mathrm{pp}$.

ISBN: 1-4039-6059-3 / 1-4039-6060-7.

Contemporary Political Theory (2003) 2, 387-388. doi:10.1057/palgrave.cpt.9300096

In the first part of this response to the UN's designation of 2001 as the 'Year of Dialogue Among Civilizations', Fred Dallmayr presents an account of what such a dialogue might involve, and why the notion of a dialogue/conversation is to be preferred to the vision of a 'clash' of civilizations, a vision that some believe vindicated by 9.11 ; he then engages with some of the voices, past and present, that he believes have much to contribute to an emerging dialogue.

Perhaps predictably, given his previous writings, Dallmayr's notion of dialogue draws heavily upon Hans-Georg Gadamer — with a very strong assist from the recent work on multiculturalism of Charles Taylor - and is developed via a friendly confrontation with the work of Jürgen Habermas, although a central metaphor, that of the 'conversation of mankind' is drawn, less predictably, from Michael Oakeshott. For Dallmayr, central to the notion of a dialogue is that no one voice should be privileged; there should be no 'symposiarch' acting as master of ceremonies. However, as a critical theorist, he also wishes to insist that it is a basic requirement of civilizational dialogue that the parties involved be committed to global civility, which involves 'a commitment to social justice and the rule of law, and a willingness to shoulder the sobering demands of "civic prudence" (phronesis)' (p 30). In Part I of Dialogue among Civilizations, this basic model is situated within a number of contexts - a perfunctory and perhaps unnecessary account of global inequalities (recounting facts of which, surely, no potential reader of this book is likely to be ignorant), a rather more interesting examination of Europe's culture and its 'other', a very interesting disquisition on the various kinds of modernity, and a slightly disappointing set of politically correct reflections from Latin America (is it really the case that the suffering and oppression of the 'common people' of the Americas began in 1492?).

The 'exemplary voices' of Part II are drawn from the world of Islam, past and present, and the Sub-Continent. These valuable studies cover Ibn Rushd (Averroes) the 12th century (C.E) Andalusian Muslim writer; Goethe's 'WestEast Divan', his encounter with the Persian poet Hafiz; the thoughts on Islam and democracy of the contemporary writer Abdolkarim Soroush; tributes to Raimon Panikkar and D.P. Chattopadhyaya and, finally, Gandhi's conception of self-rule. The point of these encounters is to illustrate that the global civility 
required of a civilisational dialogue does not have to be defined in 'Western' or European terms. Gandhian self-rule is not the same as Western selfdetermination, Soroush's democracy does not fit easily into Western templates. These studies work in their own terms but they also serve as useful introductions to thinkers who are not as well known as they should be by Western political theorists (including this reviewer).

All told then this is a worthwhile book, sensitive, intelligent and thoroughly decent in its outlook. Therein, sadly, lies a problem. It is obviously the case that, once we get beyond metaphorical language, 'civilizations' can neither 'clash' nor engage in dialogues - only individuals who may, or may not, be representative of their cultures or civilizations can actually take part in dialogues or engage in conflicts. Dallmayr's exemplary voices may not be approaching notions such as democracy and self-rule from a Western perspective, but they are plausible participants in a dialogue about global civility, as are, of course, figures such as Gadamer, Taylor and Dallmayr himself - but what of the other voices, voices (Western and Eastern) that do not belong to such plausible conversation partners? This is where clash may be the more appropriate term, and these latter voices may actually be dominant as we move into the 21 st century, as they certainly have been in the past. Gandhi's notion of swaraj remains an inspiration to all, East and West, but the Hindu nationalism of his killers has been rather more influential in the development of modern India, as their spiritual grandchildren who presently govern the land would acknowledge sotto voce while paying public tribute to the Mahatma. We are entitled to hope that Gandhi is a more authentic voice of Hinduism than his killers, but, in the last resort, this is indeterminable.

This is the first volume in a new series 'Culture and Religion in International Relations'. No one - certainly not this reviewer - would doubt the importance of these two notions for the 21st century international relations, but it is, perhaps, a little unfortunate that the first book in the series should take the form of a sermon rather than be cast in a more analytical framework. As a sermon it is suitably edifying, but those who wish to understand why religious zealots - Christian, Jewish, Islamic, Hindu and Buddhist - are causing the rest of us so much grief will not find the answer here.

Chris Brown,

International Relations Department London School of Economics and Political Science. 